\title{
Cidadania, \\ Subjetividade e Reforma Psiquiátrica
}

\author{
| 'Jubel Barreto |
}

Resumo: O presente trabalho pretende retomar a discussão das relações entre cidadania e subjetividade, com o objetivo de contribuir para uma compreensão mais rica do tema da cidadania como inerente aos objetivos a que se propõe a reforma psiquiátrica, especialmente no Brasil, onde essa preocupação aparece de forma singularmente explícita. Para alcançar tal objetivo, o trabalho se propõe a recuperar o conceito de cidadania em suas origens e acompanhar sua trajetória ao lado do itinerário percorrido pela idéia de subjetividade, apoiando-se na contribuição de vários autores e, destacadamente, nas teses de Hannah Arendt sobre a constituição da política. Como conclusão, pretende-se propor que as próprias noções de reabilitação e de empowerment adotadas na condução da reforma psiquiátrica podem ser revistas com inegável proveito no plano assistencial e com considerável ganho ético.

> Palavras-chave: Subjetividade; cidadania; loucura; reabilitação; reforma psiquiátrica.

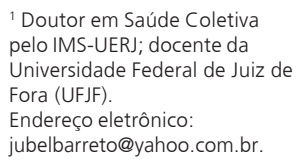


Acreditar no mundo é o que mais nos falta; nós perdemos completamente o mundo; nos desapossaram dele.

G. Deleuze

\section{Política e cidadania}

A questão da aliança entre subjetividade e cidadania, tão em voga no movimento brasileiro de Reforma Psiquiátrica, suscita algumas reflexões importantes para os que têm a responsabilidade de levá-lo adiante. Não empregamos aqui a expressão "em voga" meramente com a conotação de algo ligado à efemeridade dos modismos, mas naquela outra acepção, menos conhecida, que remete não só à idéia de remar, como também à posição do remador que marca o ritmo da remada. Rompendo com uma longa tradição que demarcou para a navegação da stultifera navis os limites familiares do mare nostrum da técnica assistencial e de suas possibilidades de aggiornamento, a Reforma Psiquiátrica lança-se às correntes dos mares menos conhecidos da política e aponta para a cidadania, não mais como um elemento inerente à paisagem, mas como o destino que persegue.

Convidamos o leitor casual destas linhas a um pequeno esforço de memória para tentar deter por um momento o sentido que recolhe das passagens em que alguma referência é feita ao termo cidadania na literatura sobre a Reforma Psiquiátrica. Podemos tentar inventariar alguns deles: cidadania significando inclusão social; significando acesso à contratualidade; portando as idéias de aquisição de autonomia; referindo-se à participação no circuito de trocas (inclusive simbólicas); englobando a idéia de empowerment (termo que pode traduzir algo como apropriação ativa e crítica de direitos), etc.

Se o leitor está de acordo com este ponto de partida, pedimos sua companhia para um curto itinerário, ao fim do qual esperamos persuadi-lo de que, na acepção em que é correntemente utilizada, a palavra cidadania: a) abre um horizonte demasiado acanhado para o projeto da reforma psiquiátrica; b) embaralha ou contribui muito pouco para desembaralhar o emaranhado contido na idéia de reabilitação psiquiátrica; c) mantém parcialmente ocultas as relaçôes entre as duas imagens da exclusão, a vinculada à cidadania e a referida à cronicidade psiquiátrica; d) não facilita a ruptura que protegeria a reforma psiquiátrica de qualquer conivência 
com o reducionismo das análises de cunho comportamentalista; e) não favorece a resistência da reforma psiquiátrica diante da maré preventivista como estratégia de medicalização extensiva do social. Talvez se possa obter, ainda, um outro ganho, especialmente valioso de nosso ponto de vista: uma ou duas indicações de que a idéia de subjetividade coletiva depende menos de alguma alquimia no plano conceitual do que da recuperação de uma imagem una esquecida nas primeiras dobras do pensamento que legamos.

É curioso observar o destino dado, na cultura que partilhamos, aos conceitos de política e de cidadania, sendo que ao primeiro conectou-se uma ressonância quase sempre depreciativa, resultado de uma trajetória de declínio ao longo da qual o conceito foi-se deixando contaminar pela atividade da política institucionalizada que conhecemos e empalidecendo até perder quase por inteiro seu valor e fascínio de origem. Se a cidadania, por outro lado, tornou-se uma noção tão valorizada e festejada, tal subida de cotação se deu ao preço de a noção perder sua nitidez de origem e passar a circular como um desses "conceitos-valise", que, em sua banalidade, só valem pela versatilidade com que podem amoldar-se ou conter habilidades tão diversas quanto regar um manacá ou escrever cartas para as colunas de opinião do leitor de algum dos nossos jornalôes. Pretendemos sugerir que o emprego mais prudente do termo cidadania e mais clemente do termo política pode carrear sentidos novos para nossas concepções acerca das estratégias de inclusão nos projetos de saúde mental.

A idéia de que sujeito e cidadão são conceitos que se sedimentaram em campos diversos, e até mesmo opostos, apóia-se em quadros hermenêuticos que já estavam presentes no pensamento de Santo Agostinho e reaparecem no pensamento de Habermas, para quem a argila que dá forma ao sujeito provém da gramática que dá a moldura para subsistemas como a família e o parentesco, em que prevalecem imagens do mundo míticas, religiosas e morais - isto é, a esfera da intimidade, do afeto e das paixões. Por outro lado, a figura do cidadão é modelada por categorias que supõem a ação racional, a impessoalidade e a objetividade, isto é, a cena pública e o jogo das aparências (HABERMAS, 1994). Esta crença está na origem da modalidade peculiar de apreensão com que as psicologias e, em especial, a psicanálise, costumam aplicarse ao discorrer sobre o espaço político, encarnado na figura do cidadão, segundo termos que operam pouco mais que um desdobramento, sobre um fundo homogêneo, das mesmas categorias aplicáveis à sua definição do sujeito. 
Por esse ângulo, não há como ocultar a precedência da noção de sujeito em relação à de cidadão, tributária do mesmo tipo de crença que reconhece a precedência das individualidades na composição do espaço coletivo. Desde Platão, tudo o que é tido como mais valioso na composição da substância do humano, como a atividade de pensar e o convite para o encontro inefável com a verdade, parece ter passado a gravitar em torno daquele ponto em que, voluntariamente afastado dos ruídos da cidade, o homem se recolhe à solidão. Por isso mesmo, o momento da filosofia de Platão é também o da inoculação do fator degenerativo que levará ao longo declínio da cidade e à sua desvalorização como expressão mais elevada da condição humana (ARENDT, 2002).

Vernant assinala que o advento da pólis grega coincide com o nascimento da filosofia, pois são indissociavelmente estreitos os vínculos entre vida da razão e vida da pólis (isto é, a política), desde que teria sido no plano da política que a razão primeiro se exprimiu e se firmou. "O que implica o nascimento da pólis, diz Vernant, é primeiramente uma extraordinária preeminência da palavra sobre todos os outros instrumentos do poder" (VERNANT, 1998, p. 41).

Castoriadis tem por certo em mente sua defesa da dimensão plural do psiquismo e do vigor que imprime à sua noção de imaginário radical instituinte, ao propor que se distinga o político (que se refere às condições que fazem de grupamentos humanos formaçôes sociais), da política (cujo projeto é o de instauração da autonomia que ele define como projeto fundante sócio-histórico e trabalho criador do imaginário instituinte). A política absorve o político, como poder explícito, e o ressignifica nos termos de sua própria gramática (CASTORIADIS, 1992), a qual reordena o espaço de convívio dentro das fronteiras que coincidem com os muros da pólis, que circunscrevem o que Arendt define de forma breve e direta como o espaço da liberdade (ARENDT, 1998a).

Antes que se abrisse a fenda a separar as margens da subjetividade e da cidadania, abriu-se o abismo entre a filosofia e a política. A cidade grega nasce "quando os remos se tornam asas", quando a palavra deixa de ser a fórmula ritual e oracular para valer e ser exercida de acordo com normas que regem o debate, a persuasão, o choque de opiniōes, das doxai (o dokei moi, isto é, o "parece-me" socrático). Nasce quando se abandonam as vagas simetrias da intimidade e se atravessam os umbrais da casa para buscar o exterior luminoso, onde tudo é público, visível, polifônico. Nasce quando o papel da força se esmaece e as relações 
hierárquicas e de domínio cedem lugar à relação de iguais, quando há um nómos partilhado por iguais, isoi. Palavra, publicidade e igualdade reúnem-se, portanto, entre os séculos VIII e VII A.C., para começar uma forma nova de relações entre homens "cuja originalidade será plenamente sentida pelos gregos" (VERNANT, 1998).

$\mathrm{Na}$ origem do pensamento grego, não havia separação entre o corpo e a alma, assim como não havia separação entre a filosofia e a cidade. A alma não passava de expressão do corpo e de seus movimentos, assim como Sócrates filosofando era plenamente um habitante da cidade. Se se supõe uma separação entre a verdade (alethéia) e a opinião (doxa), prevalecia a doxa, palavra de troca, habilidade de persuasão e moeda da argumentação. Não havia, por outro lado, separação entre a palavra (lógos) e a ação (práxis), pois a palavra servia de passaporte das realizações singulares à perenidade da memória. Separação completa havia, sim, entre as duas margens em que transcorria a vida: a esfera privada, cujo cenário era a casa; a esfera pública, cujo cenário era a ágora.

Nada do que fosse ligado ao mundo das necessidades, à reunião de indivíduos compelidos por suas obrigaçôes e carências para fazer viver e alimentar os corpos, nada do que se atrelasse à dimensão da vida como fato bruto do existente humano - nascimento, crescimento, desenvolvimento, declínio e fim da vida - escapava à lida da oikos (casa), espaço que era privado daquela liberdade que iluminava o mundo exterior da pólis.

O espaço público, o da pólis grega, era o palco do cidadão e o teatro para onde confluíam a ação e o discurso emancipados da faina e das aflições e de tudo o que faz vergar o homem sob a tirania das paixôes e dos interesses, lugar em que os grandes feitos são partilhados entre iguais e para onde deságuam em narrativas que lhes dão forma e perenidade na memória das geraçôes. E - o que pode parecer paradoxal aos nossos olhos - só na presença de outros iguais pode constituir-se a identidade, pois "a esfera pública era reservada à individualidade; era o único lugar em que os homens podiam mostrar quem realmente e inconfundivelmente eram.” (ARENDT, 1987, p. 51).

Se Sócrates voluntariamente resignou-se à sua condenação à morte por seus concidadãos, foi porque a vida para ele só se elevava da condição trivial de zoé, a esse registro da bios, que é a vida humanamente qualificada, quando podia resplandecer, integrada à simultaneidade e pluralidade das vozes dissonantes da 
pólis. Diante da vida (bios) na cidade valia a pena pôr a vida (zoé) em risco. Plein ananké, zen ouk ananké (navegar é preciso, viver não é preciso).

Em várias ocasiōes, Arendt repete que o momento decisivo na história do pensamento político ocorreu quando Platão, inconformado com o julgamento e a condenação de Sócrates, desencantou-se da pólis, colocou sob suspeita a validade da peithein, a persuasão, à qual contrapôs a dialektiké, e condenou a doxa, a opinião, preterida pela alethéia, a verdade (ARENDT, 2002). A risca ainda hesitante dessas distinções iniciais teve, no entanto, impacto comparável ao daquela risca no chão que faz com sua varinha de negrilho a Joana Carda, d'A Jangada de Pedra, de Saramago ${ }^{1}$, desencadeando os eventos que terminarão por fazer soltar-se a Península Ibérica do continente. Descrente das garantias de a doxa assegurar a Sócrates e aos sophoi a merecida imortalidade, Platão funda a Academia para ser a "nova cidade" dos filósofos, retira a filosofia da cidade e lhe designa um lugar para reordenar a pólis em conformidade com o eidos do rei-filósofo. Ao fazê-lo Platão está, na verdade, reinterpretando a política em termos pré-políticos e projetando para a nascente tradição do pensamento filosófico ocidental a sina de constituir-se como um imenso catálogo de receitas para abolir o político (ORTEGA, 2000).

Mais do que separar a filosofia da cidade e fazer da Academia uma "anti-pólis", Platão inaugura a experiência do que hoje conhecemos como subjetividade, vivida como realidade fundada no contacto individualizado com uma verdade transcendente e perene, em oposição ao mundo de aparências da cidadania e à transitoriedade da doxa. Inicia-se aí, na tradição do pensamento ocidental, um duplo movimento, simultâneo e solidário, de retirada da experiência subjetiva em direção à individualidade e à interioridade.

Esta breve incursão a um passado tão longínquo seria supérflua e mera celebração nostálgica, não fosse a oportunidade que nos oferece de reencontrar o brilho que a banalização do uso esmaeceu. "Há um componente experimental", diz Arendt, "na interpretação crítica do passado, cujo alvo principal é descobrir as verdadeiras origens de conceitos tradicionais, a fim de destilar deles sua primitiva essência" (ARENDT, 1997, p. 41).

Além disso, mais do que demonstração de apreço por uma narrativa de gênese elaborada a posteriori, o desvelamento das noçôes de política e cidadania in fieri encoraja-nos a desconstruir alguns preconceitos, sendo um deles a crença de que a política é uma função social necessária. A política não é necessária, pois, ao contrário, 
só começa onde termina o domínio das necessidades. E a política não é, em si mesma, por mais que se tenha reconfigurado, uma função social, pois a sociedade ainda é o lugar da determinabilidade do fazer impelido pela necessidade de conferir mais estabilidade e perenidade ao mundo, e não o da liberdade do agir e dizer para fruir a vida como propriamente humana naquele patamar a que se referia Aristóteles como a boa vida.

\section{Sociedade e política}

A sociedade não surgiu, portanto, de um ato criador do gênio humano, como a pólis, mas como uma modalidade de reunião no espaço privado. Surgiu, por assim dizer, na periferia da oikos, quando o labor ditado pelas necessidades da vida gerou algo como um excedente e se transformou em trabalho (poiésis), em fabricação de objetos e produção de condições novas e mais seguras à vida no mundo. Só lentamente o espaço do social foi-se descolando do estrito espaço privado para ganhar o exterior da casa (prenunciando o fato constitutivo do capitalismo moderno que, para Weber, foi a separação entre os negócios e o lar), mas não ainda o espaço público, porque ainda circunscrita a um espaço carente de liberdade, traço essencial da pólis. Os gregos sequer tinham um nome para traduzir a noção de sociedade, pois a palavra societas é de origem romana e foi no Império Romano que, em decorrência de suas estratégias de expansão e alianças, surgiu um grande contingente de indivíduos desgarrados da privacidade doméstica, mas ainda sem ingresso no círculo da cidadania, como que flutuando numa espécie de limbo entre as esferas do privado e do público.

Arendt dedicou seu livro intitulado $A$ condição humana (ARENDT, 1987) a refletir sobre a vita activa, decompondo-a nos termos fenomenológicos das três maneiras de se estar no mundo: o labor, o trabalho e a ação. O labor recobre a faixa de atividades humanas dos cuidados com a vida na sua dimensão corporal: "a condição humana do labor é a própria vida” (p. 15). O trabalho (fabricação) corresponde à diversidade de aspectos artificiais da vida humana e a tudo o que intervém para modificar o ambiente natural da vida: "a condição humana do trabalho é a mundanidade” (p. 15). Sem a mediação da matéria, a ação é a única atividade diretamente exercida entre os homens, a que escapa a toda injunção e previsibilidade dos ciclos da vida e do ambiente natural e a que se caracteriza pela ausência de limites e pela novidade e imprevisibilidade do acontecimento: a ação "corresponde 
à condição humana da pluralidade, ao fato de que homens, e não o Homem, vivem na Terra e habitam o mundo" (p. 15).

O homo laborans escapa à sua condição de prisioneiro do metabolismo incessante do labor e do consumo ascendendo ao homo faber, fazedor de instrumentos e produtor de obras que compõem um cenário mais confortável à existência, suavizam o labor e conferem certa durabilidade ao mundo. O homo faber, por sua vez, eximese da determinabilidade dos ciclos e da matéria do mundo, ascendendo ao homo politicus, realizador de ações e falador de palavras que conferem sentido e imprimem movimento à roda da história, que extrai os feitos humanos dos desvãos da frivolidade e das fadigas do esquecimento.

Se adotarmos, no lugar da divisão entre espaços privado e público, uma divisão tripartite entre casa e sociedade (que compõem o espaço privado) e cidade, podemos correlacionar o labor à esfera da casa, o trabalho ao espaço da sociedade e a ação ao universo da política.

$\mathrm{Na}$ raiz da concepção da política como algo natural e corriqueiro, cujo ponto inicial de inflexão foi a desconfiança platônica na força da palavra pública para resistir ao incessante trabalho de erosão do tempo e também a confiança na eternização das obras feitas pelas mãos dos homens, ancora-se a convicção de que a política deve zelar para tornar a vida do homo laborans mais fácil e longa, e o mundo do homo faber mais útil e belo. A política, no entanto, não nasceu como algo natural ou útil, mas como forma de convivência que assegura um lugar para a formação do próprio eu, conferindo-lhe uma identidade que é condição de sua presença e de sua diferenciação frente à realidade do mundo circundante (ARENDT, 1987).

O trabalho, resultado do "excedente" do labor, cria uma nova área híbrida entre o mundo privado e o público, onde a atividade subordina-se à necessidade expressa em leis, e não na liberdade, que coincide com a definição kantiana de espontaneidade, que se expressa no fato de cada homem ser capaz de começar uma série de novo por si mesmo (ARENDT, 1998a). O acelerado crescimento de aglomerações, que já não são contidas entre as paredes da casa e não têm ingresso ainda ao interior da ágora, vai dando forma a uma trama de alianças e uma rede de trocas que é a sociedade nascente, cujo material de liga é o trabalho.

$\mathrm{Na}$ Roma Imperial ela, a sociedade, já é mais que visível: é uma ramagem que se espraia e se espessa à sombra dos muros das cidades e mistura-se a seus rumores 
sem provar de seus sabores. Diferentemente das cidades-estado gregas, contraídas dentro de seus muros, a cidade de Roma agita-se pela vocação a expandir-se e adota, como estratégia para garantir a lealdade dos territórios anexados, a outorga da cidadania aos povos conquistados, decisão cujo efeito imediato é o de subtrair a ênfase da organização física e jurídica da pólis para fazê-la recair nas condições que resultarão na definitiva desterritorialização da cidadania (FUNARI, 2003). E surge também, pela primeira vez, a possibilidade de se pensar uma forma de cidadania em que a isonomia não é mais a condição, mas uma aspiração. Não obstante a drástica mudança no espectro de prerrogativas do cidadão, o cobertor da cidadania ainda é curto demais para cobrir toda gente. Escravos libertos, imigrantes, órfãos, viúvas, gladiadores, todo esse populacho passa a pressionar por direitos e vai sendo aos poucos incluído entre os cives minuto jure et sine suffragio (cidadãos de direito restrito e sem poder de voto).

Eis o cenário: a civitas romana já tem uma configuração que a faz bem distinta da pólis grega e a luz plena da cidadania refrata-se e espraia-se por um espectro cambiante de prerrogativas e direitos. É a esse arco-íris que o Cristianismo nascente acrescentará matizes novos.

Mais do que pelo sangue dos seus mártires, pelo espanto dos seus milagres ou pelo heroísmo dos seus evangelizadores, foi pela capilarização de sua ação de amparo anônimo e atendimento caritativo que o cristianismo primitivo pôde expandir-se e, valendo-se das garantias da própria legislação, formar uma firme rede de proteção entre os deserdados da administração romana, criando o que viria a ser a melhor versão no mundo antigo de "comunidades de base" e de uma "política social" avant la lettre, inicialmente autônoma em relação ao governo do Estado. Sua estratégia consistiu primordialmente em fomentar a criação dos collegia, um dispositivo associativista da tradição romana amparado em lei com a finalidade de se organizarem banquetes e se assegurar sepultamento digno para quem (literalmente) não tinha onde cair morto. Sua grande inovação foi não apenas a admissão, mas o incentivo à participação das mulheres nos collegia, a abertura dos seus cemitérios ao sepultamento de não-cristãos e as "campanhas" para a redenção, isto é, o pagamento de resgate para se devolver a liberdade para órfãos, viúvos, devedores e todo tipo de paroikoi $i^{2}$ (gente sem terra e sem cidadania) forçados à escravidão (HOONAERT, 2003). 
O breve brilho da pólis helênica e da civitas romana logo se esmaece, sucedendose-lhe o longo e irrefreável declínio da cidade, que cobre todo o período da Antigüidade Decadente à Alta Idade Média, até se pulverizar nas formas diminutas de aglomeração que, ainda no século IX, nem sequer eram cidades, mas domínios erigidos em fortalezas que eram, ao mesmo tempo, meros centros de administração agrícola. A partir dos séculos XI e XII, com o adensamento demográfico, as ramificaçôes das cadeias de trocas, a retomada da moeda, a melhoria das condiçôes de transporte por terra, etc., quando ocorre a gradual transformação do Ocidente em uma sociedade onde um número crescente de pessoas podia ganhar a vida através da diferenciação de ocupaçôes (ELIAS, 1993), reaparecem a cidade e o cidadão, mas o antigo espaço público dos politai não é mais que uma imagem imprecisa na bruma.

A antiga idéia de cidadania, quando ressurgir nas pequenas cidades-estado do norte da Itália, cuja expressão máxima foi a República Florentina, já estará definitivamente cindida entre o civis optime jure (cidadão de pleno direito) e o civis minuto jure, o semi-cidadão de direito restrito (ZERON, 2003), dentro de um quadro em que à idéia de cidadania estará conectada a posição do indivíduo numa escala que reflete a divisão do trabalho. É a operosidade de seus habitantes que dará a cada cidade a medida de sua grandeza e sua força; e para descrevê-la, diz poeticamente o Marco Pólo, de Ítalo Calvino³, que "teria de usar as metáforas da fuligem, dos chiados de rodas, dos movimentos repetidos que levam o mandril até os dentes da engrenagem, do cheiro de couro nas selarias e das mulheres que tagarelam enquanto tecem tapetes de ráfia."

Nessa colméia em que a cidade se transforma, à loucura não restará mais que um espaço neutralizado e pálido, na expressão de Foucault, pois o que estará talvez definitivamente perdido ao fim dessa atrofia da política como alma do espaço público será uma possibilidade de coexistência da esfera pública com a faixa, ainda tolerada até a Renascença, de possibilidades indizíveis de singularização.

Mudanças de tal porte, como sugere Elias (2003), nem são racionais (no sentido de terem sido direcionadas por intenções deliberadas), nem irracionais (no sentido de sucessões que se dão de modo aleatório ou incompreensível), mas surgem como modelos que formam tecidos de fios que se ordenam segundo planos que só revelam figuras discerníveis na perspectiva da longa duração. 
Reencontrar a cidadania in statu nascendi serve para guiar-nos à restauração de uma "visão da dignidade irredutível do começo", que, nas remotas manhãs de Atenas, foi a pólis, lugar em que a ação, em virtude de sua imprevisibilidade e irreversibilidade, resgata e atualiza o começo "que vem ao mundo quando nascemos e ao qual respondemos começando algo novo por nossa própria iniciativa” (ARENDT, 1987, p. 189-1900, começo que é, "na verdade, cada um de nós" (ARENDT, 1998b, p. 531). Se o passado, encerrado nas profundezas do tempo e desfigurado por sucessivas descontextualizações, é trazido de volta à superfície, é porque pode iluminar o tempo presente, especialmente quando as perplexidades em que este se encerra ameaçam tornar indistintos os caminhos por onde conduzir o pensamento.

Uma das mais impiedosas ironias do tempo em que vivemos é a crença no fim da tradição. Desconectados da tradição, os conceitos abdicam do eco infinito da metáfora, "naturalizam-se" e perdem a irisada promessa de significados que encerravam. O fim da tradição - citamos ainda uma vez Hannah Arendt:

não significa necessariamente que os conceitos tradicionais tenham perdido o seu poder sobre a mente dos homens. Pelo contrário, às vezes parece que esse poder das noçôes e categorias cediças e puídas torna-se mais tirânico à medida que a tradição perde a sua força e se distancia a memória do seu início; ela pode mesmo revelar toda sua força coerciva somente depois de vindo o seu fim, quando os homens nem mais se rebelam contra ela. (ARENDT, 1997, p. 53).

Se a liberdade é, como afirma Hannah Arendt, a raison d'être da política, a ocupação do espaço público pela sociedade significa simplesmente que a esfera pública foi reorientada para atender, no plano das necessidades, aos interesses da vida e da produção. Significa também que o impacto da gigantesca avalanche da esfera da vida social e econômica obscureceu por completo o âmbito da política desde a era moderna e que novas condições surgiram para tornar possível o que seria impensável: a eliminação da liberdade do espaço político, fato que, ironicamente, é reforçado pelo liberalismo que, não obstante o que o nome sugere, apega-se à fórmula "quanto menos política, mais liberdade" (ARENDT, 1997, p. 195). Como enfatiza a autora, a discriminação constitui o princípio intrínseco da sociedade na mesma medida em que a igualdade o faz no campo político, visto que, quando se cruza o limiar do mundo, é na esfera do social, "na variedade inumerável de seus grupos e associações", que imediatamente se cai (ARENDT, 2004, p. 273). 
O poder de proliferação desses dispositivos de segregação é uma das características essenciais que fazem da sociedade contemporânea um campo fragmentado, onde já não existe uma porta de ingresso, igual para todos, ao espaço público, mas, inevitavelmente, uma multiplicidade de portas com códigos de entrada que selecionam por onde se pode entrar, quem pode entrar e até onde se pode seguir.

Retomando o célebre mote dos três golpes ao narcisismo com que Freud [1917] analisa a mudança da imagem que o homem moderno tem de si mesmo, cremos que se pode afirmar que o espaço público passou por três rudes golpes narcísicos em sua trajetória. O primeiro deles consistiu na fratura entre a filosofia e a pólis, quando Platão funda a Academia, precursora da Universidade, ${ }^{4}$ e institui um primeiro espaço não-privado lato sensu a concorrer com a cidade, antecipando o embate e a posterior ocupação do espaço público pela sociedade.

O segundo revés sobreveio com a industrialização, quando o trabalho, princípio constitutivo das relações da sociedade, tendo sido gradualmente elevado a uma dignidade que não possuía nas origens, atinge o limiar da autonomização, a tal ponto que o trabalhador industrial é alienado, como demonstrou Marx, em relação ao produto do seu trabalho e já não se reconhece na obra de suas mãos. O trabalho degenera-se em esforço fútil, daí resultando que a possibilidade de reconhecer alguma dignidade na experiência individual veio a descolar-se do trabalho e refluir para o espaço da domesticidade e, por outro lado, que a falta do sentido individual no trabalho tenha vindo a formar uma "sociedade de massas" e, por fim, justificar o preconceito burguês em relação à "indolência” das massas.

Quanto ao terceiro "golpe narcísico", é preciso apreciá-lo cum grano salis, dada a dificuldade de discerni-lo numa posição de tamanha proximidade, pois aqui há que se eleger como representativo algum traço do emaranhado em que se perdem as teorizações sobre a contemporaneidade. E um traço que ganha relevo é, por ironia, o que define a contemporaneidade como sociedade dos riscos, Riskogessellschaft, na expressão de Ulrich Beck (1997). A noção de risco, no entanto, que retorna ao centro da cena, não é mais aquela da pólis grega, que refrata em mil riscas a linha do dardo lançado ao espantoso céu da irreversibilidade e imprevisibilidade da ação-palavra dos politai. Na cultura do risco da alta modernidade, o risco não significa que a vida social seja inerentemente mais arriscada, mas que a vida humana ingressa num jogo tão aleatório e à deriva de tão 
insondáveis e fragmentários processos de recombinação do tempo e do espaço que ninguém pode mais estar seguro de pertencer a algum lugar em que transcorra uma História (GIDDENS, 2002).

Dada nossa propensão a traçar paralelismos e identificar ressonâncias das mudanças no nível do habitat sobre o modus vivendi daqueles que o povoam, é sedutora a tentação de encontrar no nível do indivíduo equivalências em menor escala das mudanças ocorridas no nível mais vasto. Com a ressalva de certa assimetria nas comparações, pode-se tentar apontar na história da subjetividade três instantes análogos dos golpes narcísicos que se abateram sobre a cidadania.

O primeiro deles, que coincide com o momento da fundação da Academia e com a origem da tradição do pensamento político no Ocidente, pode ser reconhecido no redirecionamento dado por Platão, ao enaltecer, na experiência subjetiva, a retirada do universo da pluralidade da pólis para a campânula da solidão, em que se dá o encontro do ser-si-mesmo com a verdade transcendente. O primeiro "golpe narcísico" é o da retração da subjetividade aos limites do indivíduo.

O segundo golpe narcísico teria sobrevindo com a esgarçadura das comunidades - que eram uma espécie de espaço transicional (para se usar uma expressão de Winnicott) - entre a experiência de ser-si-mesmo e a de estar dissolvido na grande sociedade. É o momento representado pela industrialização, quando a experiência da subjetividade, mais do que retrair-se do espaço público ao privado, refugia-se na interioridade do indivíduo, movimento que na origem havia-se inspirado em Agostinho e nos primeiros ascetas cristãos, e passado pela "ética protestante" e pelas imagens bucólicas do romantismo, até moldar a crença de que o valor do trabalho, depreciado na automação industrial, seria recuperado na Embindung e germinaria no cálido recesso do lar burguês.

A subjetividade ganha agora a densidade das tramas da intimidade, e o sentimento de realização de si-mesmo apresenta-se como resistência às tendências à dissipação do espaço público convertido em selva hobbesiana. Nesse percurso, a subjetividade aprofunda-se e interioriza-se, numa retirada que a levará, no plano temporal, à infância; no plano espacial, ao quarto de dormir. É seguramente este o horizonte em que se perfila a imagem freudiana do ego, em oposição às "coerções" da civilização e da inevitabilidade do recalque resultante de uma árdua negociação envolvendo os interesses antagônicos do desejo interno e da lei externa. 
Assimilados os golpes da individuação e da internalização da subjetividade, assistimos agora ao terceiro assalto à experiência primordial da âncora identitária. Se as instituições da era industrial mantinham uma relação de dependência das tradições - embora suficientemente ambígua para revelar-se às vezes uma "inventora de tradições”, como sugere Halbwachs - coube à grande sociedade dos riscos completar a tarefa de desmantelamento das comunidades e, conseqüentemente, romper o fio da tradição e substituir a linearidade das narrativas pela simultaneidade avassaladora das redes de informação. E romper com a tradição resulta na superficialização da experiência do eu, pois, como afirma Arendt, a perda da tradição equivale a "privarse de uma dimensão, a dimensão de profundidade da existência humana. Pois memória e profundidade são o mesmo, ou antes, a profundidade não pode ser alcançada pelo homem a não ser através da recordação." (ARENDT, 1997, p. 131).

Paradoxalmente, no entanto, esta superficialização da subjetividade não serviu para ressituá-la no espaço do lado de fora do indivíduo (de onde foram abolidas as comunidades), mas para redirecioná-la à sua expressão meramente somática mais depauperada, a do "eu de sensações" ou da "identidade palimpsesto", na expressão de Bauman (apud LIMA, 2005).

A exaltação do trabalho, em detrimento da ação, não podia deixar de reservar à loucura o lugar da segregação, pois a loucura, para retomar a expressão de Foucault com um matiz algo diferente, é ausência de obra (FOUCAULT, 1999). De Pinel aos reformadores que conceberam o modelo das comunidades terapêuticas, a questão incessantemente reformulada é: como reservar na sociedade um lugar para a loucura?

Com amparo na visão de Giddens (2002), pode-se supor que a loucura, ao lado da criminalidade, da pobreza e de outras condições da experiência humana, só deixou de ser considerada extrínseca quando a secularização do mundo social desenvolveu, na modernidade, uma atitude que a ressignifica como algo em que a vida social se vê implicada no contexto de uma nova consciência que reconhece nela um "desvio" de fato criado por circunstâncias manejáveis e referidas a um mundo natural e social que, no conjunto, já é visto como transformável e não meramente dado. A loucura passa, portanto, a ser tomada como alvo da "segregação da experiência” (GIDDENS, 2002, p. 145, 223), que significa aqui acionar certas estratégias de ocultação que a separam da rotina da vida ordinária.

$\mathrm{O}$ mesmo fenômeno pode ser descrito de outro modo. Condições desviantes, como a loucura, são obrigatoriamente segregadas quando o espaço público é invadido 
e legislado pela sociedade. Pois a sociedade é, por definição, um arquipélago formado por ilhas de segregação e pensar-se numa sociedade capaz da iniciativa de processos inclusivos que o sejam por outra razão que sua lógica de referencialidade interna ${ }^{5}$ seria incorrer em equívocos que explicam muito dos exercícios de contorcionismo teórico que não chegam a superar os impasses em torno de programas de reabilitação incapazes de ultrapassar o limiar dos rituais de "inserçôes tópicas", correspondendo "a um tipo clássico de focalização da ação social”, como diria Castel (CASTEL et al., 2000, p. 29).

Foucault afirma que "estamos nessa dobra do tempo na qual um certo controle técnico da doença mais recobre que designa o movimento que fecha sobre si a experiência da loucura" (FOUCAULT, 1999, p. 193). Uma crença no controle técnico, ainda que remanescente, nas concepções mais avançadas da reforma psiquiátrica, é ainda o que mais ardilosamente oculta a essência das questôes levantadas pela relação entre cidadania e loucura, pois a cidadania, reduzida à sua dimensão "social", impede qualquer programa de reabilitação de recriar o espaço de liberdade que é a esfera da política.

\section{Comunidade, cidadania, subjetividade}

Como recuperar um quadro de referência em que cidadania e loucura possam darse as mãos? Sugerimos que a resposta possa se resumir a palavra: comunidade.

Diversos autores apontam na raiz da despolitização do espaço público e da instauração da sociedade de consumo a cadeia de processos erosivos que culminaram na completa supressão da comunidade. Mas o que é comunidade? Sugeriremos que a comunidade é, por excelência, o espaço da política. Sendo o espaço da política, a comunidade é também, por conseqüência, o lugar do sujeito.

A simples menção à palavra comunidade, implica, além dos equívocos debitados às formas de usá-la, o risco de suscitar interpretações pouco amistosas em virtude das conotações que adquiriu a noção de comunitarismo por oposição à noção de liberalismo, supostamente conectada à adoção de normas racionais que conferem estabilidade ao ordenamento político e às instituições sociais. Há algo de verdadeiro na imagem da comunidade como instância que realça a identidade entre seus membros em torno da preservação de códigos que instigam à ação política de caráter meramente reativo; este retrato, todavia, não diz tudo.

É claro que também a idéia de comunidade pode degenerar-se em versões depauperadas de associativismo que se limitam a criar a ficção do pertencimento, 
vindo a se constituir como ilhas de fantasia e entretenimento. Bauman (2003), por exemplo, menciona essas "comunidades", onde as elites culturais do mundo globalizado buscam mais uma ocupação do que propriamente um pertencimento, um Lebenswelt em que se cultivam afinidades freqüentemente moldadas pela indústria do entretenimento e por certa inclinação à estetização que se limita à espetacularização da existência e que, em sua descrição, são não apenas muito diferentes, mas veiculam aspirações antagônicas em relação à comunidade em seu sentido verdadeiro.

Agnes Heller define a comunidade como

uma unidade organizada, estruturada de grupos, dispondo de uma hierarquia homogênea de valores e à qual o indivíduo pertence necessariamente; essa necessidade pode decorrer do fato de se 'estar lançado' nela ao nascer, caso em que a comunidade promove posteriormente a formação da individualidade, ou de uma escolha relativamente autônoma do indivíduo já desenvolvido (HELLER, 2000, p. 70).

Dizer que o indivíduo pertence necessariamente a uma comunidade é o mesmo que dizer que a aniquilação da comunidade arrasta consigo a aniquilação do indivíduo humano, condição que só se consuma plenamente quando se propaga a "banalidade do mal", na célebre expressão de H. Arendt, como instrumento fundamental do regime totalitário que implica o colapso da comunidade e, ao mesmo tempo, a impiedosa degradação da vida individual à condição de supérflua.

Comunidade implica primeiramente acesso ao mundo, isto é, a ruptura das injunções dos laços de sangue e da esfera familiar para a constituição de um lugar no espaço público, estruturando-o como mundo de convívio. É apresentando-se como comunidade que o mundo se presentifica como "ambiente facilitador" (na conhecida expressão de Winnicott) e atualiza-se na delicadeza de um cenário em que se respira a suavidade da amizade.

É a comunidade, portanto, a esfera em que pode transcorrer a vida cotidiana iluminada de sentido e é o círculo que promete garantias para se experimentar a liberdade num lugar de trocas sem outra mediação que a dos elos invisíveis da confiança. Situandose no exato ponto de junção entre a necessidade de segurança e a vocação para a liberdade, a comunidade é o ponto de encontro da subjetividade com a cidadania.

Uma "sociedade pura", na acepção de Heller, é aquela que pulveriza a constelação de comunidades e, conseqüentemente, esfacela tanto as possibilidades de vida da cidadania quanto da subjetividade. Quando o espaço público da política está 
inteiramente capturado na teia do social, é a engrenagem burocrática que substitui a vida, são as relações de interesse que tornam obsoleta a amizade, o managerialism que ocupa o lugar da política, o consumidor que se confunde com o cidadão e o ser de conformidade que eclipsa a subjetividade.

Nessa perspectiva, defender a restauração da comunidade significa não um retrocesso saudosista à fixidez das tradições, mas defender a política ali onde ela resiste a desfigurar-se em guardiã do jogo social, defender o campo onde o acontecimento emerge criando as condições de instanciação da subjetividade.

No último livro de sua "trilogia da amizade", Francisco Ortega (2000) propõe que ao esvaziamento da esfera política deve-se contrapor a reinvenção do espaço público como o contexto intersubjetivo em que se torna possível a constituição da identidade. Pensamos que não seria uma interpretação abusiva acrescentar que o espaço público a que se refere é o da comunidade, cuja seiva é essa forma bela e criativa de convívio que é a amizade.

Também em relação à amizade há mal-entendidos que precisam ser desfeitos. Lembra-nos esse autor que o tema da amizade permaneceu periférico e limitado, na tradição filosófica e sociológica, ao nível ensaístico e do culto, devendo-se a Derrida um meticuloso trabalho de desmascaramento desses discursos como sobreposição das categorias da amizade e da fraternidade mediante a reiteração de metáforas familiares e ficções fraternalistas, segundo os cânones de uma ideologia da intimidade que esvaziou a amizade de todo conteúdo político para reduzi-la à dimensão psicológica. Acrescenta que, para Nietsche, a amizade não se situa no plano das relações íntimas entre irmãos, sendo, ao contrário, uma relação que se cultiva a uma "boa distância", distância suficiente para se resistir à tirania da proximidade, para se respeitar a alteridade e se promover a sensibilidade e delicadeza necessárias ao encontro de singularidades (ORTEGA, 2000).

Frente ao esvaziamento do espaço público e aos imperativos de intimidade, autenticidade, sinceridade, transparência, etc., as relações de amizade valorizam a distância, a impessoalidade, a hospitalidade, a urbanidade, a polidez, a teatralidade, a imaginação etc., instaurando uma atmosfera de liberdade em que já não há lugar nem para a opressão das relações familiares, nem para a compulsão à lógica dos interesses do jogo social.

Repensar a amizade, portanto, sem o recurso a imagens fraternalistas pode ser o caminho para se reinventar a amizade como exercício político e para a reconstrução 
do espaço público como lugar do agir em liberdade, onde se desenvolve a ação política como prática de novas formas de subjetivação.

\section{Subjetividade e cidadania na reforma psiquiátrica}

Sem a rede de proteção da amizade, desfigurada no espelhamento das homologias fraternizantes, e sem o horizonte da comunidade, pulverizada na "grande sociedade", ao louco só restou a alternativa de viver na condição de segregado ou deixar-se assimilar no tabuleiro em que se joga o xadrez segundo as regras impiedosas da sociedade salarial. Um programa de reabilitação que, não obstante suas melhores intenções, tome para si a tarefa de "humanizar" o controle técnico sobre a experiência da loucura, não cumprirá propriamente qualquer ação política, limitando-se a táticas mais ou menos sofisticadas de reposição do jogo social.

Um programa de saúde mental que não seja capaz de reinventar o espaço da política como instância de subjetivação e de reconhecer a precedência da ação e do discurso sobre o comportamento e a competência social não terá como proteger-se da sedução de intervenções inspiradas nas teorias psicológicas de inspiração comportamental. Não terá também argumentos a contrapor à maré do preventivismo, cujo ponto de partida é a suposição determinista que nivela a ação ao comportamento e cuja ambição é a de intervir precocemente na correia de transmissão que desemboca em leques estreitos dos modos de se ser. E, finalmente, uma prática - como tão freqüentemente se vê entre técnicos - tão ferozmente aderida a uma vulgata psicanalítica de cunho corporativista e avessa à política, não terá como compreender a dimensão de agenciamento do espaço público como constitutivo de subjetividades que até mesmo prescindem do indivíduo para se desdobrar num arquipélago de instâncias locais de subjetivação coletiva.

Em meio às pressóes de correntes conservadoras que clamam contra as ameaças de "desordem social", sob o fogo cerrado do reducionismo exumado por uma ideologia psiquiátrica que tende a patologizar qualquer "desvio", instada a provar resolutividade e com a delicada tarefa de pactuar a heterogeneidade de orientações dos profissionais que a compóem, a Reforma Psiquiátrica brasileira tem diante de si o desafio de superar não apenas a lógica da segregação como instrumento de tratamento, como também, o que é muito mais difícil, a lógica da segregação abrandada sob a forma de redes de tutela social, cujo efeito mais perverso é o de reproduzir em roupagem nova e de aparência menos bizarra a velha cronicidade psiquiátrica. 
Se não se identifica na condição do crônico um novo giro da exclusão social (algo como uma exclusão dentro da exclusão), uma nova cronicidade vai espraiarse à revelia da nossa capacidade de reconhecê-la, convertendo-se, como afirma Manuel Desviat, em questão decisiva para a credibilidade da reforma (DESVIAT, 1999). A euforia em torno de programas de monitoramento que proclamam a troca do ideal de cura pelo da qualidade de vida presta-se a representar uma tática eufemística e ao mesmo tempo irônica, de se encobrir essa questão.

Se a reforma psiquiátrica tem a ambição de ser mais que um aggiornamento de técnicas assistenciais, os profissionais que a conduzem não poderão mais perseverar em disseminados preconceitos contra a política e não poderão privilegiar como ferramenta conceitual essa tosca noção de cidadania que a assimila a noções como autonomia, contratualidade, competência social e categorias desse gênero. Não poderá, é claro, negligenciá-las; mas não poderá, também, tomá-las como justificação, devendo, antes, considerá-las condições que são pré-requisitos ao ingresso no círculo da cidadania.

A maior parte desses dispositivos para o acesso a um novo paradigma, que Guattari denominaria ético-estético, já está implantada ou em vias de implantarse, aguardando pouco mais que um novo sopro que infunda mais vida aos procedimentos adotados e um investimento mais incisivo nos CAPS (Centros de Atenção Psicossocial) e, sobretudo, na diversificação de redes comunitárias de suporte que troquem as metas conformistas de inserção social pelo compromisso de reinventar o espaço plural da política como lugar onde se desfrute da amizade, da espontaneidade, da liberdade e da criação, de um novo começo.

Não encontramos uma fórmula mais bela para encerrar estas reflexões do que estas linhas com que Arendt encerra o seu livro sobre o totalitarismo:

Mas permanece também a verdade de que todo fim na história constitui um começo; esse começo é a promessa, a única "mensagem" que o fim pode produzir. O começo, antes de tornar-se evento histórico, é a suprema capacidade do homem; politicamente, equivale à liberdade do homem. Initium ut esset homo creatus est "o homem foi criado para que houvesse um começo", disse Agostinho. Cada novo nascimento garante esse começo; ele é, na verdade, cada um de nós. (ARENDT, 1998 b, p. 531$)^{6}$. 


\section{Referências}

ARENDT, H. A condição humana. Rio de Janeiro: Forense-Universitária, 1987.

. Entre o passado e o futuro. São Paulo: Perspectiva, 1997.

. O que épolítica? Rio de Janeiro: Bertrand Brasil, 1998a.

. Origens do totalitarismo. Rio de Janeiro: Cia. das Letras, $1998 \mathrm{~b}$.

. Responsabilidade e julgamento. São Paulo: Cia. das Letras, 2004.

: A dignidade da política. Rio de Janeiro: Relume-Dumará, 2002.

BAUMAN, Z. Comunidade: a busca por segurança no mundo atual. Rio de Janeiro: Jorge Zahar, 2003.

BECK, U. A Reinvenção da política: rumo a uma teoria da modernização reflexiva. In GIDDENS, A; BECK, U.; LASH, S. Modernização reflexiva: política, tradição e estética na ordem social moderna. São Paulo: Unesp, 1997. p. 11-71.

CASTEL, R.; WANDERLEY, L. E.; WANDERLEY, M. B. Desigualdade e a questão social. São Paulo: PUC, 2000.

CASTEL, R. A gestão dos riscos: da antipsiquiatria à pós-psicanálise. Rio de Janeiro: Francisco Alves, 1987.

CASTORIADIS, C. As encruzilhadas do labirinto v. 3: o mundo fragmentado. Rio de Janeiro: Paz eTerra, 1992.

DELEUZE, G. Conversaçôes. São Paulo: 34, 2000.

DESVIAT, M. A Reforma Psiquiátrica. Rio de Janeiro: Fiocruz, 1999.

ELIAS, N. O processo civilizador, v. 2: formação do Estado e Civilização. Rio de Janeiro: Jorge Zahar, 1993.

FOUCAULT, M. Ditos e escritos I: Problematização do sujeito, psicologia, psiquiatria e psicanálise. Rio de Janeiro: Forense Universitária, 1999.

FREUD, S. Uma dificuldade no caminho da psicanálise. In: Edição Standard Brasileira das Obras Psicológicas Completas de Sigmund Freud, v. XVII. Rio de Janeiro: Imago, 1980. p. 169-179.

FUNARI, P. P. A Cidadania entre os romanos. In PINSKY, J.; PINSKY C.B. História da Cidadania. São Paulo: Contexto, 2003 p. 49-79.

GIDDENS, A. A vida em uma sociedade pós-tradicional. In GIDDENS, A; BECK, U.; LASH S. Modernização Reflexiva: política, tradição e estética na ordem social moderna. São Paulo: Unesp, 1997. p. 73-133.

GIDDENS, A. As conseqüências da modernidade. São Paulo: Unesp, 1991.

GIDDENS, A. Modernidade e identidade. Rio de Janeiro: Jorge Zahar, 2002. 
GUATTARI, F. Caosmose: um novo paradigma estético. São Paulo: 34, 2000.

HABERMAS, J. Técnica e ciência como “ideologia”. Lisboa: Ed. 70, 1994.

HELLER, A. O cotidiano e a história. São Paulo: Paz e Terra, 2000.

HOONAERT, E. As comunidades cristãs dos primeiros séculos. In PINSKY, J.; PINSKY, C. B. (Org.). História da cidadania. São Paulo: Contexto, 2003. p. 81-95.

LASH, S. A reflexividade e seus duplos: estrutura, estética, comunidade. In: GIDDENS, A; BECK, U.; LASH S. Modernização reflexiva: política, tradição e estética na ordem social moderna. São Paulo: Unesp, 1997. p. 135-206.

LIMA, R. C. Somos todos desatentos? OTDA/H e a construção contemporânea das biodentidades. Rio de Janeiro: Relume-Dumará, 2005.

MORAES, E. J.; BIGNOTO, N. (Org.) Hannah Arendt: diálogos, reflexões, memórias. Belo Horizonte: UFMG, 2003.

ORTEGA, F. Genealogias da amizade. São Paulo: Iluminuras, 2002.

ORTEGA, F. Para uma política da amizade: Arendt, Derrida, Foucault. Rio de Janeiro: RelumeDumará, 2000.

ROTELLI, F.; De LEONARDIS, O.; MAURI, D. Desinstitucionalização. São Paulo: Hucitec, 2003. VERNANT, J-P. As Origens do Pensamento grego. Rio de Janeiro: Bertrand Brasil, 1998.

ZERON, C. A Cidadania em Florença e Salamanca. In: PINSKY, J.; PINSKY C. B. (Org.). História da cidadania. São Paulo: Contexto, 2003. p. 97-113.

\section{Notas}

${ }^{1}$ SARAmagO, J. A Jangada de Pedra. São Paulo: Cia. das Letras, 1988.

${ }^{2} \mathrm{NB}$ : para-oikos (em torno da casa). Vê-se a origem do termo "paróquia".

3 CALVINO, I. As Cidades Invisiveis. São Paulo: Cia. das Letras, 1991 (citação livre).

${ }^{4}$ Talvez nem tenha sido tão por acaso que as universidades tenham vindo a constituir-se em "cidades universitárias".

${ }^{5}$ Referencialidade interna, na definição de Giddens, é a circunstância pela qual relações sociais ou aspectos do mundo natural são organizados reflexivamente em termos de critérios internos (GIDDENS, 2002).

${ }^{6}$ Apud Arendt (1998): a citação de Agostinho encontra-se em De Civitate Dei, livro 12, cap. 20. 
Citizenship, subjectivity and psychiatric reform

The present work aims to revive discussions on the relationship between citizenship and subjectivity as a means to enrich the comprehension on this theme, one of the psychiatric reform's main objectives. This discussion in Brazil is especially meaningful as it is quite explicit. This work is targeted to bring back the concept of citizenship in its own origin at the same time as it follows the trajectory of this concept along with the idea of subjectivity, based on many writers' papers but mainly on Hannah Arendt's thesis on the constitution of politics. The author intends, in the conclusion, to show that the notions of rehabilitation and of empowerment currently assumed on the psychiatric reform politics can be profitably reviewed within the assistance frame and with considerable ethical benefits.

> Key words: subjectivity; citizenship; madness; rehabilitation; psychiatric reform. 